\title{
Analisis Kinerja Pengenalan Telapak Tangan Menggunakan Ekstraksi Ciri Principal Component Analysis (PCA) dan Overlapping Block
}

\author{
R. Rizal Isnanto ${ }^{1}$, Ajub Ajulian Zahra², Eko Didik Widianto ${ }^{3}$ \\ ${ }^{1,3}$ Program Studi Sistem Kompurer, Fakultas Teknik, Universitas Diponegoro \\ ${ }^{2}$ Jurusan Teknik Elektro, Fakultas Teknik, Universitas Diponegoro \\ Email: 1rizal_isnanto@yahoo.com, ${ }^{2}$ ayub.ayul1an@gmail.com, ${ }^{3}$ didik@undip.ac.id
}

\begin{abstract}
Abstrak
Cara aman untuk mengenali seseorang adalah dengan teknologi biometrik. Telapak tangan merupakan biometrika yang masih relatif baru bila dibandingkan dengan sistem biometrika seperti wajah maupun sidik jari. Ciri yang digunakan adalah garis utama telapak tangan. Untuk mengekstraksi ciri, digunakan metode Principal Component Analysis (PCA) dan Overlapping Block, dengan metode pengenalannya menggunakan ukuran kemiripan jarak Euclidean. Pengujian dilakukan terhadap 30 individu. Berdasarkan hasil pengujian menggunakan metode PCA dengan variasi jumlah 50,75, dan 100 komponen utama dihasilkan tingkat pengenalan yang sama yaitu $90 \%$. Sedangkan pengujian menggunakan citra dengan intensitas pencahayaan yang kurang, dihasilkan penurunan pengenalan menjadi $80 \%$. Namun, untuk pengujian menggunakan 10 responden uji di luar 30 responden latih dan uji yang terdaftar dalam basisdata tidak ada yang dikenali. Sementara itu, dengan metode overlapping block, dari hasil pengujian dapat disimpulkan bahwa sistem identifikasi garis-garis telapak tangan memiliki tingkat keberhasilan pengenalan $100 \%$, baik dengan menggunakan citra uji telapak tangan yang telah dilatih maupun dengan citra uji luar. Sistem hanya mampu memberikan tingkat keberhasilan 30\% apabila intensitas cahaya ruangan dikurangi dan tingkat pengenalan $40 \%$ untuk perubahan jarak antara telapak tangan dengan kamera.
\end{abstract}

Kata Kunci: Pengenalan telapak tangan, Ekstraksi Ciri, Principal Component Analysis, Overlapping Block, Jarak Euclidean

\section{PENDAHULUAN}

Kelebihan menggunakan unsur biometrik dari tubuh manusia dalam proses identifikasi adalah dapat menghindari kekurangan sistem lainnya, seperti dokumen ataupun tanda tangan adalah tidak dapat disangkal dan diperlukan kehadiran langsung pengguna [1]. Salah satu jenis biometrik adalah telapak tangan. Garis-garis utama telapak tangan pada setiap orang tidaklah sama, sehingga karakteristik unik ini dapat digunakan pada sistem pengenalan [2]. Contoh citra telapak tangan dan bagian yang diekstraksi dapat ditunjukkan pada Gambar 1.

Sistem presensi dengan basis pengenalan garis-garis telapak tangan merupakan salah satu contoh pengenalan pola (pattern recognition) yang khusus untuk kasus telapak tangan [3]. Beberapa pendekatan untuk pengenalan objek dan grafika komputer didasarkan secara langsung pada citra-citra tanpa penggunaan model tiga dimensi [4]. Terdapat banyak cara untuk mengekstraksi ciri objek, dua diantaranya adalah algoritma Principal Component Analysis (PCA) [5] dan metode overlapping block [6] 
yang diharapkan mampu mengekstraksi ciri suatu citra, dalam hal ini adalah telapak tangan.

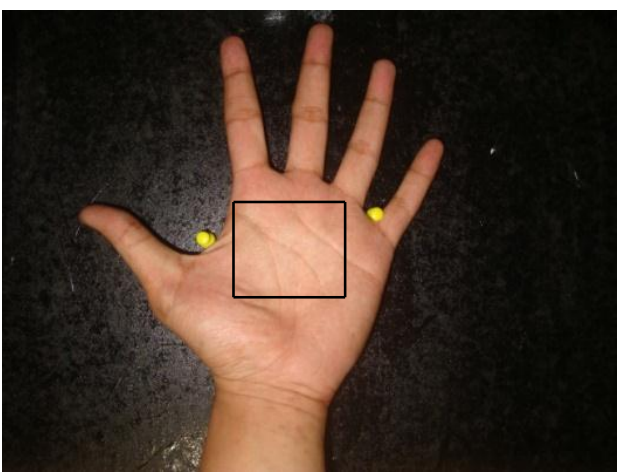

(a)

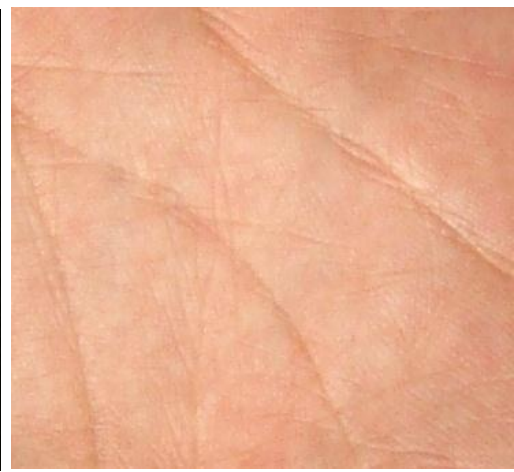

(b)

Gambar 1 (a) Citra telapak tangan dengan daerah pemotongan dalam kotak hitam.

(b) Citra telapak tangan hasil pemotongan.

Principal Component Analysis (PCA) merupakan salah satu hasil berharga dari aljabar linear terapan. Prosedur PCA pada dasarnya adalah bertujuan untuk menyederhanakan variabel yang diamati dengan cara menyusutkan (mereduksi) dimensinya. Hal ini dilakukan dengan cara menghilangkan korelasi diantara variabel bebas melalui transformasi variabel bebas asal ke variabel baru yang tidak berkorelasi sama sekali tanpa menghilangkan informasi penting yang ada di dalamnya atau yang biasa disebut dengan principal component. Dengan reduksi ini maka waktu komputasi dapat dikurangi dan kompleksititas dari citra wajah yang tidak perlu dapat dihilangkan [7]. Principal Component Analysis menggunakan vektor-vektor yang disebut dengan eigenvector dan nilai-nilai yang disebut dengan eigenvalue untuk mendapatkan fitur yang paling signifikan pada dataset [8].

Sedangkan metode overlapping block merupakan salah satu metode dari operasi blok citra. Disebut juga operasi blok-blok pembeda (Distinct Blocks). Distinct Blocks adalah partisi, berbentuk kotak yang membagi sebuah daerah matriks berukuran $m \mathrm{x}$ $n$. Distinct Blocks membagi matriks citra mulai dari kiri atas tanpa ada overlapping/ penumpukan. Jika blok tidak dapat terbagi secara pas, maka toolbox akan menambahkan zero padding [5]. Terdapat 2 jenis pembagian blok yaitu pembagian blok yang saling tumpang tindih (overlapping) dan pembagian blok yang tidak saling tumpang tindih (non-overlapping). Pada pembagian blok yang saling tumpang tindih, suatu blok dengan blok lain yang saling berdampingan terdapat sejumlah piksel yang saling tumpang tindih. Sedangkan pada pembagian blok yang tidak saling tumpang tindih (non-overlapping), piksel suatu blok dengan blok yang lain tidak saling tumpang tindih. Vektor ciri dari blok yang dibentuk dengan menghitung nilai rata-rata setiap blok [6]. Dengan rumus di bawah ini.

$$
\mu=M^{-1} \sum_{i=1}^{M} x i
$$


Dengan $M$ menyatakan jumlah seluruh piksel pada setiap blok dan $x$ adalah nilai dari piksel.

Kedua metode ekstraksi ciri tersebut akan dibandingkan menggunakan metode pengenalan yang sama, dalam hal ini adalah ukuran kemiripan (similarity measure) berdasar Jarak Euclidean [9]. Sedangkan tingkat keberhasilan pengenalan dapat dihitung menggunakan rumus sebagai berikut [10].

$$
\% \text { keberhasilan }=\frac{\sum \text { citra dikenali benar }}{\sum \text { data }} \times 100 \%
$$

\section{METODE}

\subsection{Materi Pengujian}

Materi/bahan pengujian diambil dari 220 citra telapak tangan yang terdiri atas 210 citra dari 30 responden dan 10 citra dari 10 responden. Setiap orang dari 30 responden diambil masing-masing 7 (tujuh) citra telapak tangan kiri. Dari 7 (tujuh) citra per individu tersebut, 5 (lima) digunakan untuk pelatihan, dan 2 (dua) digunakan untuk pengujian. Sementara itu, dari 10 responden yang berbeda dari 30 responden sebelumnya, diambil masing-masing 1 (satu) citra untuk pengujian luar basisdata.

\subsection{Alat yang Digunakan}

Peralatan (instrumen) yang digunakan dalam penelitian ini terdiri atas dua komponen utama, yaitu perangkat keras (hardware) dan perangkat lunak (software). Spesifikasi perangkat keras yang dibutuhkan antara lain: Seperangkat komputer dengan spesifikasi: Laptop Lenovo IdeaPad Z470, Intel I3-2350M, CPU 2.3 GHz; RAM 4096MB, HDD 750 GB, Sistem Operasi Windows 7 Ultimate (64-bit), kemudian kamera digital yang digunakan adalah Canon PowerShot A2600 16 megapiksel untuk mengambil citra telapak tangan. Sementara itu, papan hitam dan penyangga setinggi $30 \mathrm{~cm}$ digunakan sebagai media akuisisi data yang ditampilkan pada Gambar 1.

Sedangkan spesifikasi perangkat lunak yang dibutuhkan adalah: Microsoft Office 2007 untuk pengolahan kata dan Matlab R2010a untuk pembuatan aplikasi sistem pengenal telapak tangan. Matlab digunakan karena kotak kakas (toolbox) Image Processing yang dimiliki memiliki banyak tool dan fungsi yang lengkap untuk mengolah dan menganalisis citra [11]. 


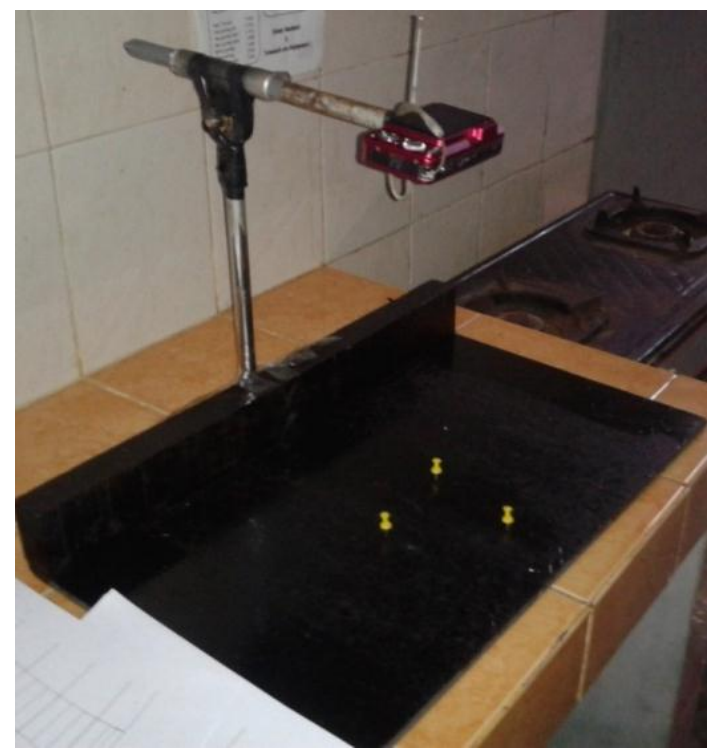

Gambar 1. Papan pengambilan data.

\subsection{Langkah-langkah Penelitian}

Pada sistem identifikasi ini masukan yang diperlukan adalah citra telapak tangan dari pengguna dan keluaranya adalah identitas dari pengguna tersebut. Gambar 2 menunjukkan diagram alir perancangan sistem untuk proses identifikasi secara umum.

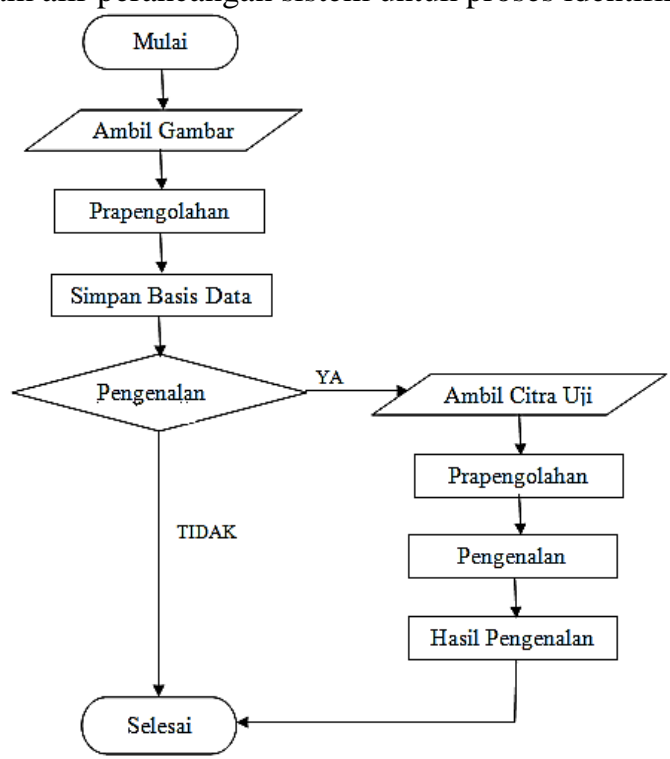

Gambar 2. Diagram alir penelitian 


\section{HASIL DAN PEMBAHASAN}

Pada bagian ini diberikan 2 (dua) pembahasan, yang pertama analisis pemanfaatan metode PCA, dan kedua adalah analisis berdasarkan metode overlapping block.

\subsection{Analisis Pemanfaatan Metode PCA}

Terdapat beberapa pengujian pada PCA ini, yaitu evaluasi pengujian pengaruh jumlah komponen utama, pengujian pengaruh tingkat intensitas cahaya, dan pengujian menggunakan data uji luar.

\subsubsection{Pengujian Pengaruh Jumlah Komponen Utama}

Pengujian data ini bertujuan untuk menganalisis pengaruh penggunaan jumlah komponen utama. Selain itu, dari pengujian ini akan dapat diketahui jumlah komponen utama yang optimal yang dapat digunakan pada program ini. Hasil pengenalan dengan variasi jumlah komponen utama dapat dilihat pada Tabel 1.

Tabel 1. Hasil pengujian pengaruh jumlah komponen utama

\begin{tabular}{cccc}
\hline No & $\begin{array}{c}\text { Jumlah Komponen } \\
\text { Utama }\end{array}$ & $\begin{array}{c}\text { Waktu Pembelajaran } \\
\text { (detik) }\end{array}$ & $\begin{array}{c}\text { Tingkat Pengenalan Citra } \\
\text { uji }\end{array}$ \\
\hline 1 & 50 & 16,75 & $95 \%$ \\
2 & 75 & 17,09 & $96,67 \%$ \\
3 & 100 & 17,37 & $95 \%$ \\
& Rata rata & 17,07 & $96,11 \%$ \\
\hline
\end{tabular}

Dari Tabel 1 dapat diketahui bahwa komposisi penggunaan jumlah komponen utama memberikan tingkat pengenalan dan waktu pembelajaran yang berbeda. Pada penggunaan 50 komponen memberikan tingkat pengenalan $95 \%$ dengan membutuhkan waktu pembelajaran 16,75 detik. Pada penggunaan 75 komponen memberikan tingkat pengenalan 96,67\% dan membutuhkan waktu 17,09 detik, pada penggunaan 100 komponen menghasilkan tingkat pengenalan 95\% dengan waktu pembelajaran 17,37 detik. Selain itu dapat disimpulkan jumlah komponen utama yang cocok digunakan untuk pengenalan pada presensi adalah 75 komponen dikarenakan selain tingkat pengenalan yang tinggi yaitu $96,67 \%$ waktu pembelajaran juga cukup cepat yatu 17,09 detik.

\subsubsection{Pengujian Pengaruh Tingkat Intensitas Cahaya}

Untuk melihat bagaimana pengaruh perubahan intensitas cahaya terhadap tingkat keberhasilan identifikasi, sistem diuji kembali menggunakan 30 citra uji dengan kondisi penerangan lampu ruangan ditiadakan. Pada pengujian ini menggunakan jumlah komponen utama 100. Hasil pengujian menunjukkan bahwa hasil pengenalan pada kondisi intensitas cahaya normal lebih baik daripada dengan penerangan lampu yang ditiadakan. Untuk penggunaan pencahayaan normal (menggunakan lampu ruang), tingkat pengenalannya adalah $90 \%$, sementara itu untuk cahaya yang ditiadakan dalam ruangan, tingkat pengenalannya adalah $80 \%$. Hal ini disebabkan 
oleh ciri pada telapak tangan akan tampak jelas pada pencahayaan normal. Sementara itu, jika cahaya ditiadakan ciri menjadi tidak bergitu jelas, sehingga pada saat ekstraksi ciri akan menghasilkan ciri yang kurang unik. Oleh sebab itu, tingkat pengenalannya pun menjadi turun.

\subsubsection{Pengujian Menggunakan Data Uji Luar}

Data uji luar merupakan data uji yang tidak termasuk dalam 30 responden yang terdaftar dalam basisdata uji maupun basisdata latih. Untuk dapat melakukan pengujian citra uji luar yang tidak termasuk dalam basisdata, digunakan nilai ambang. Tanpa menggunakan nilai ambang, citra luar akan tetap dikenali sebagai salah satu citra dalam basisdata karena proses pengenalannya menggunakan jarak Euclidean yang terdekat atau yang paling kecil.

Dalam penentuan nilai ambang, digunakan penjumlahan dua parameter statistik, yaitu nilai Euclidean maksimum dari seluruh citra uji ditambah dengan 10 persen dari nilai maksimal tersebut, dari hasil pengujian sebelumnya menggunakan citra uji. Nilai ambang dicari dengan penjumlahan antara rerata dan simpangan baku, nilainya adalah 0,006994 untuk 100 komponen, untuk 75 komponen bernilai 0,005814, untuk 50 komponen memiliki nilai ambang 0,003686. Nilai ambang ini kemudian digunakan untuk citra uji luar, diharapkan nilainnya lebih kecil dari jarak pengujian nilai jarak pengujian tersebut. Pada pengujian ini hanya menggunakan jumlah komponen 100.

Hasil pengujian dengan data uji luar dilakukan dengan 10 citra telapak tangan yang belum pernah terdaftar pada basis data menunjukkan tidak adanya citra yang dikenali. Dengan demikian, tingkat keberhasilan penolakan dari citra yang tidak dikenali adalah $100 \%$

\subsection{Analisis Pemanfaatan Metode Overlapping Block}

Pengujian dilakukan dengan menggunakan 90 citra milik 30 orang. Setiap orang diwakili 3 sampel citra telapak tangan yang 2 diantaranya digunakan sebagai citra acuan (citra pelatihan), dan 1 sisanya digunakan sebagai citra uji. Parameter yang dihitung dari pengujian ini adalah tingkat keberhasilan sistem dalam mengidentifikasi suatu telapak tangan.

Dari hasil pengujian, dapat ditunjukkan bahwa sistem mampu mengenali semua citra telapak tangan dalam keadaan pencahayaan normal. Dengan demikian, sistem ini memiliki kinerja keberhasilan sebesar $100 \%$. 


\subsubsection{Pengujian dengan citra luar}

Untuk dapat melakukan pengujian citra uji luar yang tidak termasuk dalam basis data, digunakan nilai ambang. Tanpa menggunakan nilai ambang, citra luar akan tetap dikenali sebagai salah satu citra dalam basisdata karena proses pengenalannya menggunakan jarak Euclidean yang terdekat atau yang paling kecil.

Dalam penentuan nilai ambang, digunakan penjumlahan dua parameter statistik, yaitu rerata dan simpangan baku dari hasil pengujian sebelumnya menggunakan citra uji. Nilai ambang dicari dengan penjumlahan antara rerata dan simpangan baku, nilainya adalah $0,219+0,0366=0,2556$. Nilai ambang ini kemudian digunakan untuk citra uji luar, diharapkan nilainnya lebih kecil dari jarak pengujian nilai jarak pengujian tersebut.

Pengujian dengan citra uji luar dilakukan dengan 10 citra telapak tangan yang belum pernah terdaftar pada basis data. Hasil pengujian ditunjukkan pada Tabel 2.

Tabel 2. Hasil pengujian dengan citra uji luar

\begin{tabular}{cccc}
\hline Berkas Citra & Dikenali sebagai & Jarak Euclidean & Hasil \\
\hline Luar_01 & Tidak dikenali & 0,3841 & Benar \\
Luar_02 & Tidak dikenali & 0,3518 & Benar \\
Luar_03 & Tidak dikenali & 0,3885 & Benar \\
Luar_04 & Tidak dikenali & 0,3807 & Benar \\
Luar_05 & Tidak dikenali & 0,3573 & Benar \\
Luar_06 & Tidak dikenali & 0,3402 & Benar \\
Luar_07 & Tidak dikenali & 0,4132 & Benar \\
Luar_08 & Tidak dikenali & 0,3937 & Benar \\
Luar_09 & Tidak dikenali & 0,3560 & Benar \\
Luar_10 & Tidak dikenali & 0,3764 & Benar \\
\hline
\end{tabular}

\subsubsection{Penyebab kegagalan identifikasi}

Untuk mengetahui hal-hal apa saja yang mempengaruhi hasil identifikasi telapak tangan, sistem diuji kembali dengan mengubah intensitas cahaya serta jarak antara telapak tangan dengan kamera.

\section{a) Pengaruh Intensitas cahaya terhadap proses identifikasi}

Untuk melihat bagaimana pengaruh perubahan intensitas cahaya terhadap tingkat keberhasilan identifikasi, sistem diuji kembali menggunakan 10 citra uji dengan kondisi gelap tanpa penerangan lampu. Dari pengujian diperoleh tingkat keerhasilan hanya 30\%. Tingkat keberhasilan yang sangat kecil ini disebabkan oleh intensitas cahaya yang sangat berbeda saat pendaftaran dan pengujian. Perbedaan intensitas cahaya akan mengakibatkan perbedaan saat deteksi garis. Hal ini tentu saja akan mempengaruhi perhitungan blok citra saat ekstraksi ciri. 


\section{b) Pengaruh jarak kamera dengan tangan terhadap proses identifikasi}

Sistem diuji kembali dengan mengubah jarak tangan dengan kamera sebesar $2 \mathrm{~cm}$ mendekati kamera untuk mengetahui pengaruhnya terdahap hasil identifikasi. Sistem diuji menggunakan 10 citra telapak tangan uji. Dari hasil pengujian diperoleh bahwa tingkat keberhasilan pengenalan adalah $40 \%$ apabila jarak telapak tangan dengan kamera diubah. Hal ini disebabkan saat posisi tangan diangkat, pergeseran citra dapat saja terjadi. Posisi telapak tangan yang bergeser akan mengakibatkan pergeseran blok pada saat ekstraksi ciri. Dari beberapa pengujian di atas dapat disimpulkan bahwa penerangan atau intensitas dari lampu harus selalu mirip yaitu dengan penerangan lampu minimal 20 watt di dalam ruangan. Sedangkan jarak optimal pengenalan telapak tangan adalah $20 \mathrm{~cm}$ dari kamera. Untuk variasi jarak yang kurang dari itu akan cenderung menghasilkan pengenalan yang tidak benar.

\section{SIMPULAN}

Pengujian dilakukan terhadap 30 individu. Penggunaan metode PCA berdasarkan hasil pengujian, dengan variasi jumlah 50,75, dan 100 komponen utama dihasilkan tingkat pengenalan yang sama yaitu $90 \%$. Sedangkan pengujian menggunakan citra dengan intensitas pencahayaan yang kurang, dihasilkan penurunan pengenalan menjadi $80 \%$. Namun, untuk pengujian menggunakan 10 responden uji di luar 30 responden latih dan uji yang terdaftar dalam basisdata tidak ada yang dikenali. Sementara itu, dengan metode overlapping block, dari hasil pengujian dapat disimpulkan bahwa sistem identifikasi garis-garis telapak tangan memiliki tingkat keberhasilan pengenalan $100 \%$, baik dengan menggunakan citra uji telapak tangan yang telah dilatih maupun dengan citra uji luar. Sistem hanya mampu memberikan tingkat keberhasilan 30\% apabila intensitas cahaya ruangan dikurangi dan tingkat pengenalan $40 \%$ untuk perubahan jarak $2 \mathrm{~cm}$ lebih mendekat ke kamera.

\section{REFERENSI}

[1] Kumar, A., Won, D.C.M., Shen, H.C., and Jain, A.K. 2003. Personal Verification Using Palmprint and Hand Geometry Biometric. Proceedings of AVBPA, pages 668-678, Guildford, UK. June 2003.

[2] G.S. Badrinath, K. Tiwari, and P. Gupta. 2012. An Efficient Palmprint Based Recognition System Using 1D-DCT Features, Proceedings of Intelligent Computing Technology: $8^{\text {th }}$ International Conference, ICIC.

[3] Ahmad, U. 2005. Pengolahan Citra Digital dan Teknik Pemrogramannya, Penerbit Graha Ilmu, Yogyakarta.

[4] Adipranata, R., Handojo, A., Prayogo,I., dan Yuliana, O.Y. 2005. Perancangan dan Pembuatan Aplikasi Segmentasi Gambar dengan Menggunakan Metode Morphological Watershed, Jurusan Teknik Informatika Universitas Petra, Surabaya.

[5] Putra, D. 2007. Sistem Verifikasi Menggunakan Garis-Garis Telapak Tangan, Universitas Udayana, Denpasar.

[6] Putra, D. 2009. Sistem Verifikasi Biometrika Telapak Tangan dengan Metode Dimensi Fraktal dan Lacunarity, Universitas Udayana, Denpasar. 
[7] Bong, D.B.L., Tingang, R.N., Joseph, A. 2010. Palm Print Verification System, Proceedings of the World Congress on Engineering, Vol I, London, U.K.

[8] Putra, D. 2009. Sistem Biometika, Penerbit Andi, Yogyakarta.

[9] Munir, R. 2004. Pengolahan Citra Digital dengan Pendekatan Algoritmik, Penerbit Informatika, Bandung .

[10] Hidayah, N.A. 2009. Rekayasa Perangkat lunak Pengolahan Citra dan Analisis Perilaku Intensitas Pixel ROI (Region Of Interest) Citra Radiografi Sinar-x, Skripsi, Jurusan FMIPA Universitas Diponegoro.

[11] McAndrew, A. 2004. An Introduction to Digital Image Processing with Matlab, School of Computer Science and Mathematics Victoria University of Technology, Vicoria, Australia. 
